\title{
Yirmi Çocuklu Bir Adam yahut Fettan Zaman İnsana Neler Yapmaz*
}

\section{The Man with 20 Children or What can't Cunning Time do to People}

Çiğdem Kurt Williams ${ }^{1}$ (0)

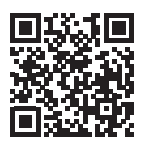

*Mehmet Hilmi'nin Molière'in Monsieur de Pourceaugnac'indan Osmanlı Türkçesine yaptığı Yirmi Çocuklu Bir Adam yahut Fettan Zaman Insana Neler Yapmaz başlıklı çevirisinin Arap harflerinden Latin harflerine aktarılmış halidir.

Teşekkür: Metnin Arap harflerinden Latin harflerine aktarılması aşamasında verdiği destekten dolayı Esra Demirkoparan'a teşekkür ederim.

'Dr. Öğr. Gör., Mimar Sinan Güzel Sanatlar Üniversitesi, İstanbul, Türkiye

ORCID: Ç.K.W. 0000-0001-7865-1645

Sorumlu yazar/Corresponding author:

Çiğdem Kurt Williams, Mimar Sinan Güzel Sanatlar Üniversitesi, Cumhuriyet Mah. Silahşör Cad. No: 89 Bomonti-Şişli, İstanbul, Türkiye

E-posta/E-mail: cigdem.kurt@msgsu.edu.tr

Başvuru/Submitted: 21.11 .2019

Kabul/Accepted: 02.12 .2019

Atıf/Citation: Hilmi, Mehmet. "Yirmi Çocuklu Bir Adam yahut Fettan Zaman İnsana Neler Yapmaz", Çeviren Çiğdem Kurt Williams. Tiyatro Eleștirmenliğive Dramaturji Bölümü Dergisi 29, (2019): 93-128. https://doi.org/10.26650/jtcd.649437

\section{$[1]^{1}$ Yirmi Çocuklu Bir Adam \\ Yahut: Fettan Zaman İnsana Neler Yapmaz}

Mudhik Komedi 3 Perde 1 Tablo

Müellifi

Paris Batakhaneleri Nam Musavver Romanın Mütercim ve Sahib-i İmtiyazı Mehmed Hilmi

Aslı Avrupa lisanlarının hemen ekserisinde bulunduğu gibi adat-ı milliyemize muvafık ve efkâr-1 umumiyemize mutabık olmak üzere yalnız personaj tabir edilen eşhasa Türk isimleri vaz olunmuş ve bu surette plan ve esas-1 lubdan ayrılınmayıp aslından mehuz bulunmuştur.

1 Köşeli parantez içindeki sayılar kaynak metindeki sayfa sayılarını göstermektedir. 


\section{İhtar-ı Mahsus}

Hulûliyle teşrif ve istiade olunan îd-1 azha-yı meymenet-intimadan sonraki yani inde'l-hisap sal-i cedid ibtidalarına taraf-ı âciziden tahminen altmış cüzü kadar olup ve sahihen mütalaaya şayan diğer bir roman neşredilecek ve hikâye-i mezkûreye tenezzülen şimdiden abone olmaklığa talip olanlara dahi bir ikram-1 naçizane olmak üzere müvezzilere ait ondalıktan sarf-1 nazar olunacaktır. Binaenaleyh abone olmaklığı talep buyuran zevatın semt-i acizi bulunan Anadolu Hisarı'na beyan-ı hâl etmeleri lazım gelip ve şehir postasıyla irsal edecekleri mektup zarfının üzerini de Anadolu Hisarı vapur memuru Hasan Efendi’ye yazmaları lazım gelir ki vürud-1 mektupta efendi-yi mumaileyh der-akab ihbar-1 keyfiyet eder ki bu suretle talibe-i matbu ve mühr-i mahsusla memhur abone senedi ita k1lınır. (Paris Batakhaneleri nam musavver romanın zeyli derdest-i tabıdır.)

Eser-i âciziden musavver Paris Batakhaneleri ile Güruh-ı Insan Nakıstır Her An ve Bahariye-i Edebiyat nam matbu kitaplar her mahalde bulunur.

Ruhsat-1 resmiyesi Maarif Nezaret-i Celilesi'nden Bilistihsal Mekteb-i Sanayi-i Şahane Matbaası'nda tab olunmuştur.

İstanbul

1297

Zirdeki iki adet mühürle memhur olmayan kitaplar indü’n-nizam mesul tutulacaktır.

\section{[2] Mukaddeme}

Her bir müellifin mahsul-i efkârına yadigâr hayatıdır. Namının unutulmaması için sahne-i matbuata türlü-be-türlü bergüzarlar çıkarmayı gönül ister. Ya asar-1 edebiye ki muarız-1 efkârdan sünuh eden zade-i tabiattır. Tiyatro maruzlarında tenvir-i efkâr eder. Tathir-i vicdan eder. Tehzib-i ahlak eder ise hiç nasıl olur ki âlem-i edebiyata arz olunmak şerefinden mahrum olsun? İnsan ki fanidir. Akıbet bu dünyadan gider. Eser ki bakidir, âlemde ibka-yı nam eder. Velev ki zerre-değer bir eser olsun. Zamana, bir tekaddüme-i naçizane yadigârını gönül arzu çeker. Mademki bir muharririn ömürler sarf ederek meydana getirdiği semere-i fuadı ki nazarlarda hayrü'l-halef olmak için yaratılmış sevgili evladı mesabesindedir. Layık mıdır ki mahv-ı abad nisyan edilsin? Mademki tiyatro halkın tehzib-i ahlakına hizmet eder, edebiyatın en birinci kısımlarındandır. Reva mıdır ki matbuat-ı cedide-i Osmaniye içinde tekessür-ü adadı terakki namına arzu olunmasın? Nasıl olunmasın ki bugün âlem-i medeniyetin hemen her bir cihetinde lisan-1 edeb tiyatroya aklen ve hikmeten mekteb-i edeb unvanını veriyor, tiyatro ibretin ayine-i endamı sayılıyor. Hakikaten de öyledir. Vicdan-1 beşerin nedim-i neşatı tevarihin de, suret-i mücessemi tiyatrolar idi ki azade-i kayd u terkim 
değil midir? Avrupa meşahir-i üdebasından bulunan eslafın bu kadar bin asar-1 edebiyesi içinde ahlaka yadigâr namına en müesser, en âşıkane ve en mudhik yazılmış bir eserleri varsa en güzelleri tiyatrolarıdır. İşte bunun için bendeniz de kendi asar-1 âcizanelerim içinde bazen de tiyatro risaleleri tab ve neşrettirmekte ve bu eserlerden birincisi edebi, fenni ve bazı mudhik hikâyatı havi (Bahariye-i Edebiyat) olduğu gibi ikincisi dahi (Güruh-ı İnsan Nakıstır Her An) namıla bir tiyatro kitabı olup üçüncüsü dahi resimleri Paris’ten celp olunmuş olan musavver (Paris Batakhaneleri) nam roman, ve dördüncüsü ise manzur ve mütalaa-güzar-1 âlîniz şerefine nail olan işbu tiyatro risalesidir ki bunlardan maada daha sair gerek tiyatro ve gerekse roman ve fenni olarak na-matbu elliden ziyade asarım mahfuz-1 kitaphane-i âcizi olup ve bunlardan entrigasyon ve Paris’te vuku bulmuş bir vaka üzerine müesses olan ve Paris'te ve tekmil Avrupa lisanlarında nüsha-yı matbuası nadir bulunan bir tiyatro kitabı vardır ki bunu bilhassa Paris Batakhaneleri nam romana zeyl edeceğim gibi asar-1 mütebakiye-i bendegânemi dahi yegân yegân kariin-i kirâmın çeşm-i tahkik ve devr-i beyn-i tadkiklerine nişane ile hadim-i maarif olmaklığg kendimce şeref-i iftihar addedeceğim. İnsanın adusu olmaması adimü'l-ihtimal idüğinden gerçi bazı hasud ve bedhahanımız bu eserlere tariz edecekler ve söylediklerini kendileri de bilmeyecekler ise de hamd olsun ki şimdiye kadar çıkardığım asar içinde hemen cümlesi nadir kalmış ve rağbet-i umumiyeye mazhar [3] olmuş bulunduğundan bittabi bunların da kil ü kal-i keenlemyekün hükmünde kalacak ve bunlara bir cevap şafi ise (vâkıâ sürme gözün nurunu ziyade eyler) (lakin göz kör olunca sürme neyler) mazmun-1 hikmet mefhumu olduğu gibi merkumlara bu hususta diğer cevap ise kariin-i kirâmca malum olan sizce meçhuldür kelamlarıdır. Mamafih manzurunuz buyurulan işbu risaleye gelince bu kitaba Fransızca Pourceaugnac namı verilir ki Fransız meşahir-i üdebasından mudhik komediler yazmakla maruf edib-i azam lebib-i muhterem (Molyer) nam zatın eser-i kalemiyesindendir ki mumaileyhin mahsul-1 kalemi olduğu için hemen Avrupa lisanlarının ekserisine tercüme olunmuştur: Binaenaleyh bendeniz de her ne kadar cevher-i mudhikeyi esas ittihaz etmiş ve lub-1 mezkurun planından bir nebze bile ayrılmamış isem de adat-ı milliyemize mutabık ve efkâr-1 umumiyemize muvafık olmak için yalnız personaj denilen eşhasa Türk isimleri vaz edilmiştir. Mahaza esna-yı tahrirde tabii vuku bulacak hataya ve nevakısın kariin-i kirâm tarafından perde-i aff-ı merhametle mestur ve nihan buyurulmasını temenni ederim. Hemen cenab-1 Hâlik kevn ü mekân-1 arş-1 azamı ve habib-i ekremi hürmetine mihr-i münir-i asuman-1 hilafet olan vücud-1 âlem-sûd Hazret-i Padişahiyi ma-teakub-ü'l-melevan arayiş-i erike-i şevket ü şan ve hemişe envar-1 eltaf ve inayat-i hümayunlarıyla cümlemizi karîrü'l-ayn şükran buyursun, amin.

Sahib-i İmtiyaz ve Müellifi

Mehmed Hilmi Bey 


\section{Eşhas}

İbiş Ağa: Ehl-i servet bir köylü olup aptal ve gayetle çirkin bir kimse

Musa Ağa: Şehirli olup eshab-1 servet ve sâmândan olduğu gibi gayetle de hasis bir kimse

Elmas Hanım: Musa Ağa'nın kerimesi ve Fettan Bey’in maşukası

Fettan Bey: Şehirli ve Elmas Hanım'ın âşığı

Birinci Hekim

İkinci Hekim

Birinci Köylü Karısı

İkinci Köylü Karısı

Bir Sekban

Birinci Delikanlı

İkinci Delikanlı

Fitne Kumkuması, Çocuklar, Eczacılar.

[4] Yirmi Çocuklu Bir Adam

Yahut: Fettan Zaman İnsana Neler Yapmaz

Mudhik Komedi 3 Perde 1 Tablo

\section{BÍRINCI PERDE}

Perde açıldıkta tiyatro sahnesi manzaraya bir sokaklık mahal irae eder.

\section{Birinci Meclis}

Elmas Hanım-Fettan Bey

Fettan Bey: Ah Elmas'ım. Meğerse en sonunda bana edeceğin bu muydu? A hiyanet! Eğer bana bunu vaktiyle söyleyeydin elbet ben de efkârımı icra etmiş olurdum. Yazık değil miydi bana? Yoksa canıma kıymak mıydı kastın?

Elmas Hanım: Hayır civanım değil. Hem de bu babda sizi temin etmek için gençliğime yemin ederim ki benim bu işlerden zerre kadar haberim yoktur. Senin, senin üzerine gül koklamak... Senin üzerine gül koklayanın ömrü gonca gül gibi sararsın solsun. Lakin ne çare 
ki babamın üzerime cari olan hükmü beni istediği gibi her kalıba döküyor. Tarife ne hacet babamın ne kadar merhametsiz olduğunu siz de biliyorsunuz a?

Fettan Bey: Eğer sen muvafakat etmemiş olsaydın acaba?

Elmas Hanım: Beyim. Doğrusu bu da reva-ı hak değildir. Sizin bu söylediğiniz sitemli sözlerin her birerleri sanki birer hançer olmuş da gönlümü parça parça ediyor... Zerre kadar merhametin olmuş olsa... Bana bu kadar zehirli sözler söylemezsin ah... Fettan... Fettan... Beyim... Sen de biliyorsun ki seni severim... Hem halimi anlatacak olursam sen de herhalde emin olacaksin!

Fettan Bey: Ah Elmas! Senin o tatlı çıtı pıtı lisanların yok mu? Benim gibi budalaları aldatacağına hiç şüphe etme... Lakin sevgili Elmas doğrusunu söyleyeyim mi? Bundan böyle hile dolaplarına aldanacak kadar ahmak değilim. Ben her bir şeyi anladım... Ne söylesen fayda etmez!

Elmas Hanım: Hakkınız var diyebilirim. Lakin vuku-u hâli [5] benden anlayıp beni cünha sahibi gibi mahcup edeydin. Veyahut ben hicabımdan senin yanında lakırdı söylemeye yüzüm olmamalıydı. Belki...

Fettan Bey: Peki sevgili Elmas mademki kendini bu babda mazur görüyorsun. Ne sebebe mebni olduğunu anlamak isterim. Nasıl olup da o ahmak kaba herife nişanlanmaya söz verdin. Lakin doğru söyle. Yalan lazım değil.

Elmas Hanım: Bu sözlere de siz inandınız öyle mi? Lakin işin sahihini anlatacak olsam emin olursunuz ya?

Fettan Bey: Evet buyurun. Söyleyin.

Elmas Hanım: Babamın desise ile beni buraya getirdiğini biliyorsun ya. Niçin olduğu, sebep hastalığımdı değil mi? Sanki biz tebdil-i hava edecektik haniya.

Fettan Bey: Elmas'çığım buraları lazım değil. Asıl can alan yerini söyle...

Elmas Hanım: Yok, işin evvelinden başladım da...

Fettan Bey: Yok efendim, sonra?

Elmas Hanım: Sonra, biz köylere gidelim de tebdil-i hava edelim diyerek beni bu herifin köyüne götürdü. Biraz bana havası fayda etmeye başladığından orada olan komşu köylü kadınları "Hanım kızım, sizi subaşlarına götürelim, gönlün gözün açılır” dediler.

Fettan Bey: Bensiz, bensiz, değil mi? Hıyanet, acaba Fettan senin o akarsu başlarında hatırına geldi mi? 
Elmas Hanım: Orasını ah bilsen! Ben her ne tarafa gittimse gözümün önünden hayalin, gönlümden efkârın bir an kaybolmazdı, lakin sen... Fettan sen ah... Hiç ummuyorum hiç...

Fettan Bey: Öyledir, size öyle demek düşer, çünkü aramızda uzaklık olduğunu bilirsiniz de.

Elmas Hanım: Şu sitemleri bırak. Beni seversen bırak da elimden geldiği kadar halimi birer birer beyan edeyim.

Fettan Bey: Söyle sevgili Elmas, söyle. Bak beni o tatlı sözlerle inandırabiliyor musun?

Elmas Hanım: Babamın hisset tabı malum...

[6] Fettan Bey: Evet!

Elmas Hanım: Arası böylelikle geçmekteyken bir gün her nasılsa köylülerin kahvesinde otururken babama orada bulunan mahalle ihtiyarları derler ki "Canım Musa Ağa size bir ricamız var. Eğer kabul ederseniz kerime hanımı İbiş Ağa'ya isteyeceğiz. Köyümüzün içinde hanedan hem zengin, kendini bilir. Zannedersek siz de buna razı olursunuz. Dügün masarifi de bizden caba" falan diyerek bunu kandırırlar. Hâlbuki babam para lakırdısını işitince ne edeceğini şaşırarak bize gelip ne anlatır... Ne sorar... Kimseye danışmaksızın hemen oracıkta tutar beni nişanlamaya karar verir...

Fettan Bey: Hemen oracıkta mı? Ah mürtekip baban... Ah!

Elmas Hanım: Evet. Bir de şuracık buracık derken bana nişan olmak üzere köyün içinden bir tarla bahşeder. Artık babam köye mal bulmuş gibi "Peki” demekten başka çare bulamaz.

Fettan Bey: Eğer böyleyse... Lakin hiç memul etmem.

Elmas Hanım: Tuhaf! Hiç memul etmez misin, ya kendisine söyletirsem?

Fettan Bey: A... Ona diyecek yok!

Elmas Hanım: Her neyse. Şimdi buna bir çare aramalı.

Fettan Bey: Nasil?

Elmas Hanım: Ben ne bileyim. Yine siz erkeksiniz. Siz bir çare bulamazsanız ben ne yaparım. Elimde ne var. Yularlı bir kuzunun ne hükmü olabilir?

Fettan Bey: A... Hakkın var Elmas'çı̆̆ım, hakkın var. Lakin (uzaktan Fitne Kumkuması'nın geldiğini görerek), hah tamam işte bizim ahbap Fitne Kumkuması geliyor, eğer bu işi o deruhte ederse ne âlâ, bakalım zaten ben biraz anlattımdı. Pek de koşarak geliyor, memul ederim ki bizi görmeğe... 


\section{İkinci Meclis}

Fettan Bey-Elmas Hanım-Fitne Kumkuması

Fitne Kumkuması: A. Evet... Evet... Sizi görmeğe, hem de güzel güzel müjdeler getirmeğe geliyorum Elmas Hanım!

Elmas Hanım: Teşekkür ederim Efendim!

[7] Fettan Bey: Bendeniz de.

Fitne Kumkuması: A. Yok yok. Bu kadar teşekkür edecek benim için büyük madde değil. Mahaza kardeşliğe ait bir vazife.

Fettan Bey: Vazife mi. Ne söylüyorsunuz. Bizim için büyük bahtiyarlıktır (Elmas Hanım’a hitaben) İşte Elmas'çığım bu zatı sizlere takdim ve tavsiye ederim, çünkü böyle alicenap bir zat bizim için her fedakârlığa hazır olduğundan bunun için ne derecelerde memnun olduğumu tarif edem.

Elmas Hanım: Bendeniz de canıgönülden her hizmetinize amadeyim.

Fitne Kumkuması: Öyle olduktan sonra her bir iş kolay demektir. Şimdi bunları bertaraf edelim de...

Fettan Bey: Canım birader daha bu menhus heriften bir haber yok mu?

Fitne Kumkuması: İşte ben de onun haberini size söylemek üzere getirdim. Demincek mahut İbiş Ağa yani Elmas Hanımefendi'nin nişanlısı olan zat şehrimize teşrif buyurdular. (Gülerek) Ha Ha ha... Tuhaf, söylemeğe de dilim varmıyor. Görseniz... Siz benden ziyade taaccüp edersiniz. Lakin bilemem nasıl olup da böyle bir esfel-i süfela adama sizi nişanladılar!

Fettan Bey: Canım nasıl adam rica ederim. Şunu bize de tarif et.

Fitne Kumkuması: Nasıl olacak. Size şu kadar diyebilirim ki dünyada ne kadar çirkin, ne kadar bed suret adam varsa bu adamdan güzel ve gayet naziktir diyebilirim. A! Doğrusu böyle bir adama Elmas Hanım gibi nev-civanı tevzice doğrusu bir vakit gönlüm razı olmaz. Bunun için her ne ki fitnelik lazım gelirse elimden geldiği kadar icraya hazırım, çünkü vicdanım buna hiç kail olmuyor. Bilmem siz nasıl tahammül ediyorsunuz?

Elmas Hanım: Ah! Efendim, benim gibi bikes bir kızın neye kudreti olabilir! Siz her bir işi hazırlayın da ben de elimden gelse firara kadar gözüme alıp efkârınıza mugayir bir harekette bulunmayacağıma söz veririm. 
Fitne Kumkuması: Öyle olduktan sonra ben de lazım olan adamları hazırladım. Siz de lazım olacakları [8] hazırlayın, çünkü böyle işlerde gayet temkinli davranıp öyle bir desiseler kullanmalı ki kolaylıkla her tuzağımıza tutulup sersem balık gibi bir yere kımıldanamasın!

Fettan Bey: Evet evet öyle etmeli.

Elmas Hanım: Peki efendim. Lakin nikâh maddesine ne desise kullanacaksınız?

Fitne Kumkuması: Ben işi o raddeye götürmem. Onun için esef etmeyin. (Dışarıya bakarak) Hah işte kendisi de geliyor. Aman sizi burada görmesin rica ederim beni yalnız bırakınız efendim yalnız.

Fettan Bey: Peki efendim... Peki. (Elmas Hanım'la Fettan Bey giderler)

\section{Üçüncü Meclis}

Fitne Kumkuması-İbiş Ağa

İbiş Ağa: (Dışarıya söylenerek hiddetle) Be hey çapkınlar ne istersiniz benden?

(Dışarıdan bir takım ahali gülerek) Ha ha ha...

İbiş Ağa: Hele bir daha gülün de bakın.

Dışarıdan: Ha ha ha...

İbiş Ağa: Sizin hiç utanmanız arlanmanız yok mu?

Dişarıdan: Ha ha ha...

Fitne Kumkuması: (Güya İbiş’i himaye yollu görünerek) Canım ne istersiniz bu adamdan? İbiş Ağa: Evet, ne istersiniz benden?

Dışarıdan: Ha ha ha...

Fitne Kumkuması: Hiç utanmanız yok mu sizin? Bu adamın gülecek nesi vardır?

İbiş Ağa: Evet. Nem var gülecek? Kambur muyum, zanbur muyum?

Dışarıdan: Ha ha ha...

Fitne Kumkuması: Böyle zata riayet her vakit sizin borcunuzdur.

İbiş Ağa: Bana riayet etmeyenlerin vay haline!

Dışarıdan: Ha ha ha... 
Fitne Kumkuması: Bu adama istihza edenlerin cezasını [9] ben vereceğim. Anladınız mı ben vereceğim.

İbiş Ağa: Benim gibi bir adamın buraya gelmesi adeta size bir büyük şereftir.

Dişarıdan: Ha ha ha...

İbiş Ağa: (Huzzara hitaben) Siz ne gülüyorsunuz? (Dışarıya hitaben) Benim kim olduğumu sonra anlarsiniz.

Dışarıdan: Ha ha ha...

Fitne Kumkuması: (İbiş Ağa'ya temenna ederek) Canım efendim. Sizi istihza edenlerin tarafından tarziye etmek üzere affınızı rica ederim. Kusurlarına nazar buyurmayınız.

İbiş Ağa: Teşekkür ederim. Mademki rica ediyorsunuz ben de kabul ettim.

Fitne Kumkuması: Canım efendim, uzaktan teşrif-i alinizi görür görmez efendime yani zatıalinize görüşmek şerefine nail olduğum için kendimi ne derece bahtiyar addettiğimi tarif edemem.

İbiş Ağa: Teşekkür ederim, hakikaten sizin gibi bir zat ile görüştüğüme çok memnun oldum.

Fitne Kumkuması: Zat-1 âlâlarının burada ikamet buyurdukları kadar hizmet-i aliyelerinde istihdamı canıdilden arzu ettiğim için zannederim kabul buyurmanızda da tereddüt etmezsiniz efendim.

İbiş Ağa: A! Yok yok. Ben de sizin gibi bir refik-i sadığa muhtaçtım. Memnun oldum.

Fitne Kumkuması: Buraya teşrifiniz zannederim bir iş zımnında olmak gerek?

İbiş Ağa: Ha evet. Evet, cemiyet etmek için.

Fitne Kumkuması: Cemiyet mi, nasıl?

İbiş Ağa: Evet evlenmek için. Burada cemiyet etmeye karar vermiştik de.

Fitne Kumkuması: Teehhül mü edeceksiniz efendim?

İbiş Ağa: Evet, evlenecektim de...

Fitne Kumkuması: Anlaşıldı efendim. Acaba kimin kerimesini alacaksınız?

İbiş Ağa: Hiç kimsenin. Lakin buraya gelişim Musa Ağa'nın kızını nişanlamıştım onun cemiyetini [10] yapacağım. (Kendi kendine) Ne kalın kafalı adam bu hiç lakırdı anlamıyor. 
Fitne Kumkuması: Canım efendim. Kimin dediniz? Musa Ağa’nın kerimesini mi?

İbiş Ağa: Ha evet niçin taaccüp ediyorsunuz?

Fitne Kumkuması: Hiç... Hayır!

İbiş Ağa: Yok, çünkü mademki ahbabız...

Fitne Kumkumas1: Evet, lakin!

İbiş Ağa: Lakin sonra?

Fitne Kumkuması: Bir şey yok efendim, bir şey yok.

İbiş Ağa: Demek ki ahbaplığg terk ediyorsunuz!

Fitne Kumkuması: Hayır velakin bu öyle bir şeye... Hayır, efendim hayır yakışmaz!

İbiş Ağa: Rica ederim beni meraktan kurtarın: Anlamak isterim.

Fitne Kumkuması: Mademki anlamak istiyorsunuz... Size muhtasarca söyleyeyim.

İbiş Ağa: Hah tamam gördünüz mü? Ahbaplık böyle olmalı, buyurun.

Fitne Kumkuması: Şimdi diyeceğim şu ki, bu Musa Ağa kerimesi Elmas Hanım...

İbiş Ağa: Evet, evet, Elmas Hanım... Ta kendisi, ey?

Fitne Kumkuması: Bu Elmas Hanım'ın hali... Eğer kendisini adeta fahişedir desem vâkıâ mübalağa etmiş olurum. Biraz hoppadır desem bu da pek az olur. Şimdi işi hafifçe anlatıp sizi de meraktan kurtarmak için adeta size layık olmayıp açıkçadır derim vesselam!

İbiş Ağa: (Hiddetle) Ne! Ne demek! Beni bunlar ne zannediyorlar! Ben öyle dolma yutar miyım?

Fitne Kumkuması: Ama efendim olabilir ki zann-1 âcizanem gibi de olmaya. Belki siz işi daha etraflıca tahkik edebilirsiniz velakin.

İbiş Ağa: Hayır, hayır, ben kendi işimi kimseye sormam. Sizin kelamınız bana kâfidir. Hem şimdi kendilerine haber gönderir nişanlarımı geriye alırım. Evet, evet, ben bilirim onlara edeceğim işi. Ne demek bunlar benimle muhatap mı ediyorlar? Yoksa beni altı aylık çocuk mu zannediyorlar? 


\section{[11] Dördüncü Meclis}

Fitne Kumkuması-İbiş A ğa-Fettan Bey

Fettan Bey: (İbiş Ağa'yı güya evvelden tanıyormuş gibi boynuna sarılarak) Vay efendim! İki gözüm, teşrifiniz bizi ne derecede memnun etti!

İbiş Ağa: (Yavaşça Fitne Kumkuması'na hitaben) Kimdir bu?

Fitne Kumkuması: (Omuzlarını silkerek yavaşça) Galiba eski ahbaplarınızdan biri olmak gerek.

Fettan Bey: (Bi’l-defaat boynuna sarılıp öperek) Aman efendim, sizi görür görmez güya dünyalar benim oldu. Ah iki gözüm! Alem ah! Zatıalinizin teşrifleri mucib-i iftiharımızdır.

İbiş Ağa: (Fitne Kumkuması'na gizliden) Hiç tanıdığım değil. (Fettan Bey’e hitaben) Teşekkür ederim efendim. Lakin bendenizi biliyorsunuz ama nerede görüştük, hatırıma gelmiyor.

Fettan Bey: Acayip! Hiç mi hatırınıza gelmiyor? Çok şey... Bendenizi pekâlâ bilmelisiniz ama!

İbiş Ağa: (Fitne Kumkuması'na hitaben) Asla hatırıma gelmiyor. (Fettan Bey’e) Nerede görüştük acaba?

Fettan Bey: Nerede mi? Tuhaf! Haniya Tataroğlu'nun düğününde sofra başında heybecinin Receb’iyle ettiğiniz kavgayı unuttunuz mu?

İbiş Ağa: (Fitne Kumkuması'na hitaben) Pek güzel tanıyor (Fettan Bey’e) Evet, evet, hatırıma geldi, ne dersin herifle hayli kavgalar ettik. O bana bir tokat vurdu ama ben de karşılık ona ses çıkarmadım.

Fettan Bey: (Fitne Kumkuması'na hitaben) Evet, öyle oldu ağa Recep'in bir tokadını yedi ama bu da ona ses çıkarmadı ya... Ey efendim, inşallah hemşireler filanlar iyidirler!

İbiş Ağa: (Gizliden Fitne Kumkuması'na hitaben) Ay akrabalarımı da biliyor! Ne tuhaf!

Fitne Kumkuması: (İbiş Ağa’ya hitaben) Evet efendim, pek güzel biliyor. Galiba eski bildiklerinizden olmalı.

İbiş Ağa: (Fettan Bey’e) Evet, cümlesi iyidirler.

Fettan Bey: Hamdolsun efendim. Allah ömürlerine bereket [12] versin. Ey efendim, şey... Haniya sizin bir de...

İbiş Ağa: Ha anladım, valideyi soracaksın, değil mi? 
Fettan Bey: Evet, evet, valide hanım nasıldırlar, iyiler mi efendim?

İbiş Ağa: (Gülerek) Ha ha ha... Artık biçare ihtiyarladı. Ocak başından kalkmağa iktidarı yok. Yalnız tütün ve kahveyle uğraşıyor. (Fitne Kumkuması'na hitaben) Soyumu sopumu hep tanıyor.

Fitne Kumkuması: (İbiş’e) Galiba siz de kendisini tanıdınız a?

İbiş Ağa: Hiç bilemedim. (Fettan Bey’e) Haniya dayımın oğlu vardı...

Fettan Bey: Evet, evet, bildim. Haniya bir gün öküz arabalarıyla bizi bağlara götürdüydü...

İbiş Ağa: (Ağlamak göstererek) O delikanlı sizlere ömür vefat etti!

Fettan Bey: (Ac1yarak) Vah vah vah! Demek ki neslinizden bir büyük telefat vuku bulmuş!

İbiş Ağa: Ne söylüyorsunuz? Acımadık adam kalmadı!

Fettan Bey: Şey... Nasıldır efendim, haniya amcanızın oğlu?

İbiş Ağa: Hayır, benim amcamın oğlu yoktur, kızı vardır.

Fettan Bey: Evet, evet, kızı diyecektim, şaşırdım. Affedersiniz. İnşallah iyidirler.

İbiş Ağa: Ah, günden güne büyümekte. Evvelki gibi değil şimdi, pek yaramaz oldu, görsen.

Fettan Bey: Ah efendim, sizin oraların o güzel havası, o güzel sular, o tatlı meyveler, o muhabbetli insanlar, canım efendim, neler neler, maydanozlu köfteler hiç hatırımdan çıkmaz.

İbiş Ağa: Demek ki, sahihan oralarda bulunmuşsunuz, öyle mi?

Fettan Bey: Ne demek, sahih demek de söz mü? O akarsu kenarları, üzüm bağları hiç hatırımdan çıkar mı?

İbiş Ağa: (Fitne Kumkumasına hitaben) Hiç bilemiyorum!

Fitne Kumkuması: Efendim, eski ahbaplarınızdan olmak gerek.

[13] Fettan Bey: Ey burada ne ettiniz? İnşallah fakirhaneye teşrif edeceksiniz. A! Doğrusu, memnun oldum.

İbiş Ağa: Hayır, hayır rahatsız etmek istemem. Şimdiki halde bir oda tuttum, orada kalacağım.

Fettan Bey: Ne dediniz? Oda mı tuttunuz? Hiç öyle şey mi olur? Allah esirgeye, bu kadar vakitten beri olan ahbaplığımız mahv mı olacak?

İbiş Ağa: Rahatsız etmek istemem, affedersiniz. 
Fettan Bey: Yok, vallah olmaz. Sizin gibi bir zat han odasında... Ne demek!!!

Fitne Kumkuması: (İbiş’e hitaben) Davete icabet lazımdır. Eğer gitmezseniz çok ayıp olur zannederim.

İbiş Ağa: Canım, pekâlâ ama eşyalarım hep odada, nasıl olur?

Fettan Bey: Zararı yok efendim, şimdi haber gönderir getirtiriz. Ne bahis var!

İbiş Ağa: Mademki istiyorsunuz, maal-memnuniye teşekkür ederim!

Fettan Bey: Bendeniz de teşekkür ederim. Bu babda memnuniyetimi tarif kabil değildir. Buyurun efendim. (Giderler)

(Tablo perdesi açılır)

(Birinci ve İkinci Hekimler ile Fettan Bey görünür)

Fettan Bey: (Birinci Hekim’e hitaben) Efendim, sizi çağırttığımın sebebi, akrabamdan birinin şuuruna halel geldiğinden gece gündüz evlenmek arzusunda olduğu cihetle olup hâlbuki teehhül maddesi bunun illetini bütün bütün fenalaştıracağı şüphesiz olduğundan bu babda sa’yınızı diriğ buyurmamanızı rica ederim.

Birinci Hekim: Affedersiniz delikanlı, siz bizim ne güne hekim olduğumuzu daha iyi fehmetmeğe muktedir değilsiniz. Hâlbuki bir hasta ki benim elime geçtiği halde o hasta ya iyi olur yahut mahvolur.

Fettan Bey: Teşekkür ederim efendim. Lakin ricam yalnız bunun içindir ki şu evlenmek maddesinden fariğ olsun da nasıl olursa olsun.

Birinci Hekim: Evvela bir hastanın hastalığını teşhis etmek için lazım olan konsültasyonu refikimle bi'l-icra hastanın illeti neden ibaret olduğunu anlayıp derhal mualecesine [14] teşebbüs ederek bir an evvel iyiliğine gayet dikkat ve itina olmak lazım olduğu için iki refik geldim. Siz bir kere hastayı buraya getirin de alt tarafinı biz icra ederiz.

Fettan Bey: Baş üstüne efendim, ama lakin gözediniz ki elinizden kaçmasın.

Birinci Hekim: Ne dediniz? Kaçmak mı? Hiç senin hasta olup da düştüğün hekimlerin elinden kaçtı̆̆ın var mı?

Fettan Bey: A, hakkınız var efendim, hakkınız var!

Birinci Hekim: Şimdi onlar lazım değil. Haydi, siz gidin de hastayı gönderin, sonrasına karışmayın.

Fettan Bey: Başüstüne efendim (diyip gider). 


\section{Beşinci Meclis}

Birinci Hekim-İkinci Hekim-İbiş Ağa

(İbiş Ağa hekimleri görünce taaccüp eder ve hekimler İbiş Ağa’yı görünce bir tarafına geçip diğeri bir tarafına geçerek başlarını eğmeğe başlarlar. İbiş Ağa da bunlara taklit olarak başını eğer. Sonra biri tarafina dönüp bakar ki diğer hekim de başını eğer. İbiş Ağa yine ona taklit olmak üzere başını eğer. Nihayet birkaç kereler böyle yapıp İbiş’in nabızlarını hekimler ellerine alarak İbiş Ağa’yı bir sandalye üzerine oturturlar.)

İbiş Ağa: (Taaccüple) Bu ne? Bunlar kim?

Birinci Hekim: Şu anda nabızları elimizde olan hastamızın düçar olduğu illet evvela kendi vücudunun iştahı olan hastalıkla beyinlerinde olan hüsn-ü muaşeretten neşet etme bir hastalık olup ancak bu vücudun zafiyetiyle hastalık galebe etmiş olduğundan naşi bu hale giriftar olduğu bî-iştibahtır.

İkinci Hekim: Evet, öyle olmak gerek.

İbiş Ağa: (Hiddetle yerinden sıçrayarak) Bu ne demek? Ben hasta değilim!

Birinci Hekim: (İbiş’e) Yemeğe iştahın var mı?

İbiş Ağa: Evet, var.

Birinci Hekim: Çok fena nişane!

İkinci Hekim: Su içmeğe arzun var mı?

İbiş Ağa: Hay hay!

İkinci Hekim: Pek fena alamet!

[15] İbiş Ağa: (Hiddetle yerinden kalkarak) Bu ne canım, bu ne demek, ben hasta değilim be! Açım, aç!

Birinci Hekim: Hastamızın düçar olduğu illet evvela kendisinde olan derin düşünüp gece ve gündüz gözünün önüne diğer bir kimsenin hayalini getirerek onun hüsn-ü cemaline üftade olup en sonunda, yani şu anda bizim teşhis ettiğimiz hastalığına, bu hastalığın ismine aşk illeti derler ki o illet kendisini düçar eder ve bu illetin hekimler dahi mualecesinden aciz olup yalnız...

İbiş Ağa: (Yerinden kalkarak) Of! Şimdi patlayacağım bu ne tuhaf adamlar be!

Birinci Hekim: (İbiş’ in omzuna basıp oturtarak) Evet, bu aşk illeti öyle bir illet-i şeydadır ki iptidası gönülden, intihası yürekten hasıl olup hekimü'l-hükema bu illete bir vech ile mualece 
bulamaz. Böyle hastaların bir tarafı bağ-ı bostan, diğer tarafı gül-ü gülistan ile müzeyyen olup bazı kere şu macunu dahi istimal etse belki fayda hasıl olur.

İbiş Ağa: (Yine yerinden kalkarak) Be canım, ben hasta değilim. Eğer siz hekimseniz başkasına bakın. Oh ne belaya çattık be!

Birinci Hekim: (Hiddetle oturtarak) Ne demek! Sen hastasın, biz de hekimiz ve seni iyi edeceğiz.

İkinci Hekim: Nasıldır efendim o macun?

Birinci Hekim: Dinle. Evvela bu şahbaz bülende bir dirhem naz, iki dirhem eda, üç dirhem istiğna, dört dirhem cilve, beş dirhem letafet, altı dirhem nezaket, yedi dirhem muhabbet, sekiz dirhem şetaret, dokuz dirhem ünsiyet, on dirhem ülfet olup bunların cümlesini bir araya getirerek vefa havanında dövüp sefa tülbendinden eleyerek kullanılmamış efkâr çömleğine konduktan sonra, hasret ulüvvünden kaynatıp sabah akşam vuslat kaşığıyla istimal ettirmeli.

İbiş Ağa: (Yerinden kalkıp bağırarak) Yeter be! Aman ya Rab, ne belaya uğradım. Bırakın beni!

İkinci Hekim: Eğer ki bu da fayda hasıl etmezse de mesela?

Birinci Hekim: Bununla da şifapezir olmazsa, ekser akarsu kenarlarında ve çimenler üzerinde eğlendirilip ahenk ve çalgı, güzel şarkılarla kendisini yani efkârını tahvil ile beraber bir meslek-i [16] diğer ittihaz etmeli. Bendenizce böyle, şimdi siz buyurun.

İbiş Ağa: (Yerinden kalkarak) Vay, bu da mı başlayacak, ay şimdi yangın var diye bağırırım. Defolun şuradan bela herifler! Ben hasta değilim! Anlatamadık mı?

İkinci Hekim: (Omuzlarından oturtarak) Allah etmesin ki sizin tertip ettiğiniz mualecelere asla lakırdı söylemeğe haddim olsun. Yalnız, ben de dâhil konsültoda olduğum için şu kadarcık ilave-i makal ederim ki evvela bu şahbaz bülendin...

İbiş Ağa: (Hiddetle kalkarak) Ay bu da başladı, ey şimdi deli olacağım.

İkinci Hekim: (Yine oturtarak) Evvela bu şahbaz bülendin kendisine mahsus oturduğu odanın içerisini beyaz boyayla badana ettirip bu ise zihninin aydınlığına bir faide-i kesîr olmak üzere lazımdır zannederim.

İbiş Ağa: (Yerinden kalkarak) Canım, daha bıkmadınız mı?

İkinci Hekim: (Oturtarak) Saniyen, bir büyücek bez derinine bir kıyye kadar tuz doldurup anlının bir tarafından diğer tarafına kadar kuşatarak sıkı sıkıya bağlamak lazım gelir ki bu da zihninin açılmasına bir medar-1 kâfidir zannederim. 
İbiş Ağa: (Hekimleri taklit ederek) Zannederim, artık işin yoksa zannet!

İkinci Hekim: Salisen, hastamızın düçar olduğu illetin önünü kesmek için iki kollarından derin kan aldırıp ziyadece aktıktan sonra ayaklarından dahi iktizasına göre bir miktar icap eder zannederim.

İbiş Ağa: Yine zannederim. (Yerinden kalkarak) Bıktım be! Bu ne kadar zannederim daha bitmedi mi? Ay şimdi siz de benden dayak yiyeceksiniz zannederim!

İkinci Hekim: Bundan sonra, zat-1 hekimanenizin tarif ve tertip ve talim buyurduğunuz, yani akarsu kenarıyla güzel şarkı ve beste çayırlar üzerinde ikamet, sahrada, gülistanda sefa bahş olmaları lazım geldiğini âcizane bendeniz de itiraf ederim. Bâki.

(Bu aralık ellerinde kimisinin hap, kimisinin ilaç şişesi, kimisinin şırınga ve su bardakları olduğu halde bir takım hekim çırakları gelip İbiş’e vererek)

[17] (Zirdeki vodvili icra ve terennüm ederler)

Sağlık sağlık sağlık

Etme dert ve figan

Meserret ve şadlık şadlık

Besler ömrünü fidan fidan

Dertlerin görünce geldik biz tedbire

Sağlık sağlık sağlık

Kara sevda derdi

Bir nev' deliliktir

Tenkiye hikmeti

Maraza faydadır

Ümidi kesmeyin

Pek yaraşır şu tertip

(2) Al efendim uygun uygun

(2) Al bir tertip macun 
Gel hora tep eğlen

Et şarabî bazı

İster sarhoş da ol

Tenkiye yetmezse

(2) Al efendim uygun uygun

(2) Al bir tertip macun

Hassiyettir hoknacıktır

(8) Al şunu yut şunu

(8) Al şunu al

(8) Al şunu yut şunu

(8) Al şunu al

(Eyzan)

(Diyerek İbiş Ağa’ya verirler. İbiş ise şaşırarak altındaki sandalyeyle bir koyuntudan öbür koyuntuya kaçmakta ve merkumlar dahi İbiş’i kovalamaktalarken birinci perde iner.)

\section{İKİNCI PERDE}

(Perde açıldıkta birinci perdenin aynı manzarası)

(Evvelen sokak müşahede olunup Birinci Hekim’le Fitne Kumkuması görünür.)

\section{Birinci Meclis}

Birinci Hekim-Fitne Kumkuması

Fitne Kumkuması: Acayip şey! Sizin gibi bir ehl-i hazıkın elinden kaçsın! Hiç bu olur şey midir? Hem böyle bir şey ki şimdi siz bu hususta külli akçe kaybetmiş olacaksınız. Hem öyle bir para ki başkalarına da iktizası olabilir.

Hekim: Ben o parayı hiçbir vakitte kaybetmedim. Hem ona gösteririm ki benim gibi bir hekimin elinden kaçmak nasıl olurmuş!

Fitne Kumkuması: Evet efendim. Layık olanda göstermeli. Hususuyla siz onu iyi edecektiniz. Ben sizin yerinizde olsam, kendisi iyi oluncaya kadar evlenmesine bir vech ile ruhsat vermezdim. 
Hekim: Evet, evlenmek onun kârı değildir. Ah! Hain, alçak! Acaba sen benim elime bir daha geçmez misin?

[18] Fitne Kumkuması: Elbette efendim, elbette. Nasıl geçmez?

Hekim: Kendisi şimdi nerededir dersiniz acaba?

Fitne Kumkuması: Efendim, zann-1 âcizaneme nazaran, Musa Ağa'nın evinde olmak gerek, çünkü onun buraya gelmesinin sebebi, Musa Ağa’nın kızı kendisine nişanlı olup cemiyetlerini icra etmek içindi. Hâlbuki...

Hekim: Ne? Cemiyet mi? Ben ona cemiyet etmeği gösteririm! O Musa Ağa dediğiniz adamın evi nerededir?

Fitne Kumkuması: Efendim, size tarif edeyim de (Bu aralık uzaktan Musa Ağa’nın geldiğini görerek) Hah, tamam işte. Kendisi de buraya doğru geliyor. Bendenize ruhsat verin ki sizinle beraber görmesin (Gider).

\section{İkinci Meclis}

Hekim-Musa Ağa

Hekim: İbiş Ağa'nın kayınpederi siz misiniz?

Musa Ağa: Evet, neden sordunuz?

Hekim: Siz onu kendinize damat ederseniz bilmiş olunuz ki evladınıza büyük keder etmiş olacaksinız.

Musa Ağa: Niçin efendim? Sebebi?

Hekim: Çünkü kendisinin şuuruna halel gelmiş olmakla onu bize teslim ettiler. Ben de kendisini iyi etmeğe vaat etmiştim. Hâlbuki hengâm-1 konsültoda kendisi firara karar verdi.

Musa Ağa: Ne demek istediğinizi anlayamıyorum. Rica ederim canım efendim, şu işi bana izah edin!

Hekim: Nasıl anlayamıyorsunuz? Kendisi adeta delidir. Ben hekimim, onu iyi etmek isterim. Velakin...

Musa Ağa: (Taaccüple) Deli midir dediniz?

Hekim: Evet, delidir. Hem fena halde! Şimdi elimden kaçtı. Eğer kızını ona verecek olursan sonra evladının da telefine bâis olursun. 
Musa Ağa: (Korkarak) Aman ya Rab, bu ne bela!

Hekim: Size tekrar ederim, bilmiş olun ki [19] o benim elimden kaçtı. Onun yerine seni iyi edeceğim.

Musa Ağa: Lakin ben hasta değilim!

Hekim: Ne vazifem benim. Bana bir hasta lazım. Ama gerek sen ol, gerek başkası olsun! Ben şimdi gelirim (Gider).

Musa Ağa: (Yalnız) Bu ne demek? Zorla mı beni iyi edecek? Ya ben hasta değilsem ne yapacak? Çok şey, çok şey. İyi ya şimdi nasıl etmeli? Bakındı şu derde, meğer bizim damat da deliymiş! Acaba buna ne çare bulmalı?

\section{Üçüncü Meclis}

Musa Ağa- (ve tebdil-i kıyafetle) Fitne Kumkuması

Fitne Kumkuması: Canım efendim, buraya düğün yapmak için gelen İbiş Ağa’nın kayınpederi siz misiniz?

Musa Ağa: Evet efendim! Lakin neden sordunuz?

Fitne Kumkuması: (Gitmek gibi yürüyerek) Hiç efendim, bu kadarcık malumat bendenizi memnun etti.

Musa Ağa: (Arkasından tutarak) Rica ederim biraz beni dinleyin!

Fitne Kumkuması: (Avdet ederek) Ne istersiniz efendim?

Musa Ağa: Sizi memnun eden malumatın esasını anlamak isterim.

Fitne Kumkuması: Lakin efendim, bu olamaz.

Musa Ağa: Bu ne demek? Mademki bendenize riayetiniz vardır.

Fitne Kumkumas1: Evet efendim.

Musa Ağa: Ey işin aslını anlamak isterim diyorum...

Fitne Kumkuması: Peki, söyleyeyim. Sizin damadınız olan zat ki İbiş Ağa...

Musa Ağa: Ey...

Fitne Kumkuması: O adamın pek çok tüccarana külli borcu vardır. Hatta benim de alacağım vardı. Geçenlerde, yani çoktan beridir bizden kaçtı̆̆ 


\section{Musa Ağa: Sonra efendim?}

Fitne Kumkuması: Bizi şu vech ile temin etti ki ben Musa Ağa'nın kerimesini alacağım. Bana biraz müsaade verin de kızının bana getirdiği çeyiz [20] ve iratlarla sizin borcunuzu kâmilen eda edeyim diye...

Musa Ağa: (Kendi kendine) Ay ay ay... Bakındı derde! (Aşkâre) Lakin ben... Şey, benim kızımın çeyizi, iradı yoktur. Siz ona inanmayın.

Fitne Kumkuması: Vay, sahih mi? Mademki böyledir, şimdi gider biz de onun hakkından geliriz! (Gider)

Musa Ağa: (Yalnız) Bu ne demek? Adeta bizi soymağa gelmiş... Hiç öyle şey mi olur? Hayır ben, ben de kızımı veremem. Zorla olmaz ya! Vermeyeceğim vesselam.

\section{Dördüncü Meclis}

Musa Ağa-İbiş Ağa

İbiş Ağa: (Kendi kendine) Al şunu, yut şunu. Şifalıdır, pek hafiftir, küçücüktür. Mide açar, derde deva... Oh, aman ya Rab, bu ne haldi başıma gelen! Şimdi ne tarafa baksam bana hekim görünüyor. Elim bir şeye dokunsa ilaç zannediyorum. Ah acaba bu ne dertti başıma gelenler! Hiç de korkusu hatırımdan çıkmayacak, nasıl etsem?

Musa Ağa: (İbiş Ağa’yı görerek istihza ile) Maşallah damat bey efendim, maşallah! İbiş Ağa: Bırakındı sen de Allah’1 seversen. Sağlıkla kızını bana nişanlamaya idin!

Musa Ağa: Sağlıkla sen de istemeyeydin, utanmaz!

İbiş Ağa: İyi ya sana ne oldu?

Musa Ağa: Daha ne olacak? Senin gibi herifin eline evladımın düştüğüne acıyorum! İbiş Ağa: Nem var? Ne olmuş ki acıyorsun?

Musa Ağa: Daha ne olsun istersin a düdük!

İbiş Ağa: (Hiddetle) Vay, bana mı bu?

Musa Ağa: (Hiddetle) Evet sana! Ne demek istersin?

İbiş Ağa: (Keza) Demek isterim ki düdük sensin!

Musa Ağa: Behey budala, bir kere düşün başında olan işleri... 
İbiş Ağa: (Hiddetle) Ne var benim başımda?

Musa Ağa: Ne olacak, bir takım hekimler elinden kaçmışın, adeta deliymişin a budala! İbiş Ağa: Sen ona ne bakarsın? Bir oyundu ki bana oynadılar...

[21] Musa Ağa: Ne? Nasıl oyun? Beni de mi kandırmak istersin?

İbiş Ağa: Niçin kandıracağım? Böyle bir hile tuzağına sen de düş de bak!

Musa Ağa: Ey, o y1lan yahut hile, her neyse...

İbiş Ağa: Evet, evet, hile tuzağı adeta!

Musa Ağa: Peki, haydi o öyle olsun. Beş on kişiye olan borcunu benim kızımın çeyiziyle verecek olduğuna dair ettiğin vaadinin de mi aslı yok? Ey, bakalım buna ne diyeceksin? $\mathrm{Ne}$ kaba uyduracaksın bakalım şunu söyle!

İbiş Ağa: Nasıl borç? Nasıl beş on kişi? Nasıl çeyiz? Nasıl irad? Bu ne demek Allah'1 seversen?

Musa Ağa: Ay, bunları da mı inkâra cesaret ediyorsun? Aferin. Lakin ben dolma yutmam! Bana Zekizade Musa Ağa derler. Anladın mı? Bana lo lo lo olmaz, burasını bilmiş ol da...

İbiş Ağa: Ne derlerse desinler! Benim sana lo lo lo etmeğe de vaktim yok. Bu olan işlerin cümlesi sizin soyunuzun sopunuzun ettikleri hile dolabıdır, anladın mı?

Musa Ağa: Artık sen onu benim gecelik kavuğuma anlat! Bak ben dinlersem!

İbiş Ağa: İster dinle, ister dinleme. Bana hiç kabahat bulmağa hakkın yok kayınpeder efendi.

Musa Ağa: Hem daha doğrusunu istersen...

İbiş Ağa: Hem daha doğrusunu istersen senin kızını almağa da pek o kadar iştahım yok!

Musa Ağa: Hah hah hah, güleyim bari! Zahir ben de sana kızımı vereyim diye adaklar adadımdi?

İbiş Ağa: İster ada, ister adama. Orası bana lazım değil. Ben olanı sana söyledim.

Musa Ağa: Ben de canıgönülden pek dinledim, damat efendi.

İbiş Ağa: Ey, lakin bu kadar da istihza çok oluyor affedersiniz!

Musa Ağa: Lebbeyk. Çok mu oluyor dediniz? Vay, zatıalinize hiddet teşrif etti galiba öyle mi? 


\section{[22] Beşinci Meclis}

İbiş Ağa-Musa Ağa-Elmas Hanım

Elmas Hanım: Ah benim velinimetim babacığım, bir müjde işittim, acaba sahih mi?

Musa Ağa: Ne? Nasıl müjde bakayım?

Elmas Hanım: Beni nişanladığınız İbiş Ağa buraya teşrif buyurmuşlar, acaba gerçek mi?

Musa Ağa: Evet ama sağlıkla gelmesin. Ben seni ona vermeyeceğim!

İbiş Ağa: (Hiddetle) Sen de sağlıkla verme. Tuhaf be! Canımdan ne istiyorsun? Bana kastın ne?

Elmas Hanım: (İbiş Ağa'yı görerek) Vay! Hakikatli babacığım, beni nişanladı̆̆ınız İbiş Ağa dedikleri zat bu mu?

Musa Ağa: Evet ama artık kızım biz o işten vazgeçtik.

Elmas Hanım: Sebep? Niçin babacığım Niçin vazgeçtiniz?

Musa Ağa: Olamayacak kızım! Senin aklının ereceği şey değil!

Elmas Hanım: (Suni surette ağlayıp İbiş'in boynuna sarılarak) Hey hey hey... Ben nişanlımı isterim! Ben nişanlımı isterim! Kuzum babacığım, canım babacığım, size rica ederim, beni nişanlımdan ayırmayın!

İbiş Ağa: (Elmas Hanım’ın elinden kurtulup kaçarak) Bu ne? Bu sırık kız?

Musa Ağa: (Elmas Hanım’ı bir tarafa alarak) Kızım, Elmas Hanım, çekil diyorum sana! Böyle şeyler kız kısmına ait bir vazife değildir!

Elmas Hanım: (Yine koşup boynuna sarılarak) Babacığım, babacığım, kuzum babacığım, canım babacığım! Elmas sana kurban olsun! Beni nişanlımdan ayırmayın rica ederim. Yoksa sonra ben de telef olurum!

İbiş Ağa: (Yine kaçarak) Vay gidi Elmas vay! Adeta kubbesiz kuvars taşı bile değil!

Musa Ağa: (Yine Elmas Hanım’ı bir tarafa alarak) Sana diyorum Elmas! Haydi eve! Ha sonra fena olursun!

Elmas Hanım: (Ağlayıp hem de tepinerek) Ben kocamı isterim, ben kocamı isterim! Çünkü vermeyecektiniz de evvel beni niçin nişanladınız? (İbiş Ağa’nın üzerine koşarak) Ah benim billur gibi parlayan civan efendiciğim! Eğer beni [23] sana babam vermeyecek olursa 
kendimi öldürmek bir işten bile değil! İnsafsız, bari sen merhamet et de beni bunların elinden kurtarmağa bir çare taharri et. Ne olursun!

İbiş Ağa: (Elmas Hanım'ın elinden kaçarak) Aman ya Rab, bu ne aşüfte şey. Zorla bana varmak istiyor. Hiç de böyle karı görmedim!

Musa Ağa: Ey Elmas, artık çok oldu! Sözümü dinle yoksa...

Elmas Hanım: İstemem, istemem, istemem! Ben başka koca istemem! Ne yapayım! Zorla olmaz a! İşte gönlüm bunu sevdi. Dünya güzeli olsa bir pare. (İbiş’in boynuna sarılarak) Ah benim iki gözümün bebeği! Siz de bana hiç merhamet etmiyorsunuz! Baksana ne söylüyorlar, a hiyanet!

İbiş Ağa: (Yine kaçarak) Ne adamlar! Bu ne acayip şeymiş! Of, ne tarafa kaçayım ben de şaşırdım!

Musa Ağa: (Elmas’ın elinden tutup götürerek) Kız sözümü dinle! Yoksa dayak yiyeceksin!

Elmas Hanım: (Suni ağlayarak) Ben kocamı isterim! Ben kocamı isterim! Ben kocamı isterim! (Hem tepinir hem gider).

İbiş Ağa: Maşallah, maşallah! Doğrusu haset olunacak bir evlat! Darısı isteyenlere!

Musa Ağa: Damat, gördün mü evladımı? Nasılmış ya, kocasına ne kadar mutia şeydir.

İbiş Ağa: Oh! Allah için diyecek yok! Doğrusu bulunmaz kelepir. Allah, isteyenlere bağışlasin!

Musa Ağa: Demek sana ha?

İbiş Ağa: Allah esirgeye, bana mı? Başkasına ver babam, başkasına. Bana lüzumu yok!

Musa Ağa: Ben de pek bayıldım! Baksana, ağaya lüzumu yokmuş. Bende öyle bir kız bulunsun, elimi öpene veririm.

İbiş Ağa: Olabilir a! Lakin ben istemem! Allah sana bağışlasın!

Musa Ağa: Böyle nazik, güzel, ehl-i hüner, [24] gayet politikalı bir kızım olur da kısa ot mu çeker?

İbiş Ağa: Öyle ya, öyle ya. Hiç öyle kelepir bulunur mu? İhtarınız abes!

Musa Ağa: Hay hay, sen almazsan başkasını bulurum. (Gider)

İbiş Ağa: (Yalnız kalarak) Hay anasını. Ne murdar şey! Adeta baş belası, kız değil a, lakin 
neydi başıma gelenler! Babası kızından, kız babasından berbat! İyi oldu ki yakamı çabuk siyırdım! Hele hamdolsun!

\section{Altıncı Meclis}

\section{İbiş Ağa-Birinci Köylü Karısı}

Karı: (Koşarak ve sık sık soluyarak) Ah dizlerim, nefesim kesildi. İlahi! Allah’tan bul, kör ol! Alçak herif! Ben de ettiğini yanına bırakırsam namert olayım (der, İbiş Ağa'nın yakasından tutar).

İbiş Ağa: Bu ne? Bu ne bela ya!

Karı: Söylesene alçak köpek! Söylesene! Beni görür görmez dilin mi tutuldu?

İbiş Ağa: (Taaccüple) Canım ne istersin benden?

Karı: Ne istersin ne demek? Daha ne isteyeceğim? Beni gûnagûn hilelerle aldat, nikâhına al, sonra da bırak kalk savuş. Bu Allah’tan reva mıdır? Ben sana ne ettim? Mademki böyle edecektin, niçin evvelden beni aldım? Niçin beni çoluk çocuğumla sefil ü sergerdan bıraktın?

İbiş Ağa: (Taaccüple) Nasıl aldın? Nasıl çoluk çocuk? Ne söylüyorsun?

Karı: Vay! Hicabından yere geçecekken bir de utanmadan inkâra mı kalkışıyorsun?

İbiş Ağa: Be kadın, ne oldu ki, ne var?

Karı: Daha ne olacak? Vay şimdi de karı-koca olduğumuzu inkâr edeceksin öyle mi?

İbiş Ağa: Vay ben senin kocan miyım?

Karı: Ey! Bilmiyor musun?

İbiş Ağa: Yok. Sahih mi söylüyorsun?

Karı: Tu bire utanmaz! Böylelikle elimden kurtulmak istiyorsun ha!

İbiş Ağa: Aman Allah! Şimdi çıldıracağım! Canım ben seni...

[25] Karı: (İbiş’in lakırdısını keserek) Sen benim kim olduğumu zahir şimdi öğrenirsin, öyle mi?

İbiş Ağa: Hanım, Allah için bırak yakamı. Benden ne istersin?

Karı: Daha ne isteyeceğim, karınım diyorum! İşitmiyor musun? 
İbiş Ağa: İyi ya, ne zaman ben seni aldım? Nerede sen bana vardın?

\section{Yedinci Meclis}

İbiş Ağa-Birinci Köylü Karısı-İkinci Köylü Karısı

İkinci Karı: (Soluyarak ve sıkı sıkı koşarak kendi kendine) Ah, aman ya Rabbi! Bir kere elime geçse, ben biliyorum ona yapacağımı (Bu aralık İbiş’i görüp yakasını tutarak) Hah sen burada mıdın? Utanmaz herif! Allah’tan korkmadan beni bırakıp niçin kaçıyorsun? Benim sana ne ettiğim vardı?

İbiş Ağa: (Taaccüple) Bu ne? Bu da mı bir bela?

İkinci Karı: Söylesene utanmaz, söylesene!

İbiş Ağa: Canım ne istersiniz benden?

Birinci Karı: Ne isteyeceğim? Söylesene bu karı kim?

İkinci Karı: Ne isteyeceğim? Bilmiyor musun? Ben senin karın olduğumu ne çabuk unuttun? İbiş Ağa: (Taaccüple) Ne? Sen de mi benim karımsın?

İkinci Karı: Evet. Vay, inkâr mı edeceksin?

Birinci Karı: Söylesene... Kimdir bu karı?

İbiş Ağa: Aman ya Rab! Bugün gökten karı ile hekim mi yağıyor acaba?

İkinci Karı: Bir takım tatlı dillerle beni kendisine celp ettikten sonra yüzüstü bırakıp kaçmak reva-ı hak mıdır?

İbiş Ağa: Canım, ne diyorsunuz? Aman, rica ederim beni bırakın! Ya Rab, ne söyleyeceğimi de şaşırdım.

Birinci Karı: (İkinci Karı'ya hitaben) Siz ne istiyorsunuz kadın bu adamdan? (İbiş’i çeker)

İkinci Kadın: (Birinci Karı'ya hitaben) Siz ne istiyorsunuz [26] bu adamdan? (Bu dahi İbiş’i kendine çeker)

İbiş Ağa: Ay şimdi çatlayacağım!

Birinci Karı: Bu benim kocamdır! Anlıyor musun? Kocamdır! (Kendine çeker)

İkinci Karı: Hayır, hayır. Bu adam benim kocamdır, anlıyor musunuz? Benim kocamdır. (Kendine çeker) 
İbiş Ağa: Ey, bırakın da lakırdınızdan sonra...

Birinci Karı: Ben bu adamın on üç senelik karısıyım. On üç, anladınız mı? (Kendine çeker) İkinci Karı: Bu adam benim sekiz senelik kocamdır! Sekiz senelik! (Kendine çeker)

Birinci Karı: Demek ki ben senden eskiyim (Kendine çeker).

İkinci Karı: Bu halde beni senden sonra almış demek oluyor. Elbette beni çok sever (Kendine çeker)

İbiş Ağa: Of be canım, bırakın artık be! Bu ne insafsızlık!

Birinci Karı: Benim ondan on iki tane çocuğum var (Kendine çeker).

İkinci Karı: Benim de sekiz evladım var! Hem hepsi de oğlan (Kendine çeker).

Birinci Karı: Ben ona gösteririm karı üzerine karı almağı (Yine kendine çeker).

İkinci Karı: Sen gösterirsin de ben yakasını bırakır mıyım? (Çeker)

İbiş Ağa: (Bağırarak) Ay yeter be!

Birinci Karı: Ben ilk karısıyım. Cezasını çektirmek bana düşer (Çeker).

İkinci Karı: Beni sevdi de aldı. Hayır, bana düşer (Çeker)

Birinci Karı: Yok efendim. Bana düşer (Çeker).

İbiş Ağa: Canım durun da söyleyin de ben de anlayayım. Ne söz anlamaz karılarmışsınız be!

Birinci Karı: Ne anlayacaksın! Beni inkâra mecalin kaldı mı?

İbiş Ağa: Peki şimdi sen benim karım mısın?

Birinci Karı: Evet, ya çocukların...

[27] İbiş Ağa: Vay! Çocuklarım da mı var? Hiç bilmiyorum. (İkinci Karı'ya hitaben) Sen de mi benim karımsın?

İkinci Karı: İnkâr mı edeceksin? Çağırayım mı çocuklarımı?

İbiş Ağa: Vay çocuklarım da mı geldi? Aman ya Rab! Hiç böyle şey görmedim.

İkinci Karı: Evet zahir görmedin, kolaylıkla hazır evlat sahibi oldun daha ne istersin?

Birinci Karı: Zahir görünce de inkâr edeceksin galiba... 
İbiş Ağa: İyi ya, nerede çocuklarım?

Birinci Karı: Gelin Muhsin, Veli, Dursun, Ramazan, Osman, Recep, Kasım, Cafer, Reşit, Raşit, Hurşit, Memiş, Şuayp. Geliniz oğullarım, geliniz.

İkinci Karı: Bayram, Tuzsuz, Şaban, Kerem, İsmail, Ahmet, Mehmet, Hüseyin. Geliniz çocuklarım, geliniz.

(Bu aralık birçok çocuklar gelip İbiş’in başına üşerler. İbiş Ağa “Aman bu ne” diyerek kaçmağa başlar. Çocuklar ise İbiş’in arkasını bırakmayıp "Baba baba baba” diyerek kovalarlar. İbiş iki tarafa doğru kaçar, çocuklar takip etme esnasında ikinci perde dahi iner).

\section{ÜÇÜNCÜ PERDE}

(Perde açıldıkta sahne yine sokak olup Fitne Kumkuması ile Fettan Bey müşahede olunur)

\section{Birinci Meclis}

\section{Fitne Kumkumas1-Fettan Bey}

Fitne Kumkuması: Ey beğendin mi olan işleri? Ne dersin? Dünyada avanak olursa da bu kadar olur! Herif sersem balıklar gibi her attığımız ağa tutuldu. Lakin bir tarafından âcizane hayli zahmet çektim ha! Zannederim burasını da inkâr edemezsiniz.

Fettan Bey: Ah benim hakikatli dostum! Senin bana bu babda ettiğin iyilikleri sırtım teneşire gelse unutmak acaba mümkün müdür? Asla! Gece ve gündüz hasretle yandığım bir tanecik Elmas'ımdan ayrılmış, lakin bugün sayende büyük iltifatına nail olduktan başka bundan böyle her vech ile yani kendisinin benden gayrı kimseye verilmekliği bile mümkünsüz olacağına şüphem kalmadı. Hiç böyle insaniyet hatırdan çıkar mı?

[28] Fitne Kumkuması: Yok yok, bu kadar iltifata nail olacak bir şey icra etmedim. Yalnız benim ettiğim kardeşliğe ait bir vazife yoktur.

Fettan Bey: Ne demek senin bana ettiklerini değil ahbap, kardeş bile olsa yine hakkını ödemekliğimin de ihtimali yoktur.

Fitne Kumkuması: Şimdi onlar lazım değil. Sen işin daha tuhafını bilmezsin. Herifi buradan kaçırmak için bir hile daha buldum. Eğer söylesem zannederim sen de beğenirsin.

Fettan Bey: Nasil?

Fitne Kumkuması: Dinle. "Senin halin şimdiden sonra fenalaştı. Burada eğer daha oturursan seni fena halde rezil edecekler. Hususuyla sen de oldukça memleketin hanedanından bulunmuşsun, eğer beni kendine muhib-i sadık bilirsen buradan kaçmanın kolayına bak" dedim. 
Fettan Bey: Sonra?

Fitne Kumkumas1: Sonrası, herif meğerse dünden razı ama ne fayda, herifin ilk geldiği vakitler ettiğimiz iş kendisine fena halde dokunmuş da nasıl kaçayım beni yine görürler de berbat ederler diye onu düşünüyormuş. Bir de ben işi anlatır anlatmaz aman buna bir çare bul ki beni kimse bilmesin diyerek elimi bırakıp ayağıma sarılıyor. Bizde de zaten hileler mevcut. Tutar herife güya iyilik ediyoruz gibi bir şey tarif ederiz.

Fettan Bey: Ne?

Fitne Kumkuması: "Seni burada çokluk bilmezler, velakin kendine yaşmak ferace ile güzelce karı kıyafetine girersin. Ol-vakit büsbütün billursuz olursun. Daha rahat istediğin gibi ferah ferah kaçabilirsin" dedim.

Fettan Bey: Ey ne cevap verdi size?

Fitne Kumkuması: Ne cevap verecek? Herif dünden memnun dedim a. Hazırlanıp şimdi buraya gelecek. İhtimaldir şimdi neredeyse (Uzaktan İbiş Ağa'nın geldiğini görerek) Hah! İşte, kendisi de geliyor. Aman seni burada görmesin. Haydi, git dediğimi icra et (Fettan gider).

\section{İkinci Meclis}

Fitne Kumkuması-İbiş A ğa

İbiş Ağa: (Yaşmaklı olduğu halde eda ile gelir) [29] Abo canım, abo, abo... Ne demek efendim?

Fitne Kumkuması: Maşallah, maşallah, kırk bir buçuk maşallah! Maşallah. Eğer ki bendeniz zatıalinizi mukaddem görüp ülfet etmemiş olaydım... Sahihan tanımayacaktım. Aman efendim, ne güzel de yaraşmış! Tıpkı kibar familyalarına dönmüşsünüz.

İbiş Ağa: Lakin dostum, bunun içinde de fena halde sıkıllyorum, ne dersen de!

Fitne Kumkuması: Zararı yok efendim. Alışırsınız, bir şey demek değil.

İbiş Ağa: Hiç ummuyorum ama!

Fitne Kumkuması: Şimdi efendim, buradan birlikte gideriz. Ben sizi caddeye kadar götürürüm. Sonra oradan tenha yola çıktık mı yaşmağı feraceyi çıkarırsınız olur gider.

İbiş Ağa: Öyle mi edelim?

Fitne Kumkuması: Evet, evet, öyle yaparız. İyi olmaz mı efendim?

İbiş Ağa: Peki, sen bilirsin, ne dersen ben razıyım. 
Fitne Kumkuması: Lakin efendim, şimdi bir şey var.

İbiş Ăga: $\mathrm{Ne}$ ?

Fitne Kumkuması: Biraz karı tavrı talim etsen olmaz mı?

İbiş Ağa: Nasıl etmeli onu?

Fitne Kumkuması: Haniya kadınların yürümesi ve lakırdıları nasılsa biraz meşk edelim de şayet yolda giderken bize rast gelenler sizi kadınlardan fark edemesin.

İbiş Ağa: İyi dedin. Ah, şuradan selamet bir kurtulabilsem! (Ahaliye) Şurada da bu adamdan başka kendime bir dost bulamadım (Aşkâre) Peki, peki yaparım dostum, yaparım.

Fitne Kumkuması: Evvela merde sesinizi değiştirmelisiniz efendim ki kadınlar gibi olsun. Sonra yürümeniz benzesin.

İbiş Ağa: (Yürüyerek ve iki tarafa sallanarak karılar gibi edayla) Böyle mi?

Fitne Kumkuması: Evet, evet... Biraz daha, biraz daha...

[30] İbiş Ağa: (Ziyadece sallanarak) Böyle mi?

Fitne Kumkuması: Hah şöyle! Bakınız tıpkı kadınların yürümesinden fark olunmuyor! Şimdi isminizi tesmiye edelim.

İbiş Ağa: Eskimizi nesime mi vereceğiz?

Fitne Kumkuması: Hayır efendim. Adınızı kadın adı koyalım diyorum.

İbiş Ağa: Hah, peki efendim (Ahaliye) Hiç böyle dost bulunmaz. (Aşkâre) Nasıl isterseniz öyle yapalım efendim.

Fitne Kumkuması: İsminiz Dilruba olsun iyi mi?

İbiş Ağa: Peki, adım Dilruba, babamın adı budala kaplumbağa. Öyle ya soy sop hep havuz kenarı mahsulüyüz, değil mi?

Fitne Kumkuması: Estağfurullah efendim. Kendi kendinize iftira ediyorsunuz!

İbiş Ağa: (Karı taklidi yaparak) Dinle beni dostum. Kız halayık, bana baksana seni gidi kahpe seni! Artık hiç sözümü dinlemiyorsun! Alimallah seni bu hafta pazara götürür satarım. Bana kimse karışamaz. Senin paranı ben verdim!

Fitne Kumkuması: Oh oh oh, bakınız ne âlâ oluyor tıpkı hanımlara benzediniz! 
İbiş Ağa: Baksana Veli, sana söylüyorum (şaşırarak erkek sesiyle) öküzleri çifte götürdün mü?

Fitne Kumkuması: Aman efendim, ne yaptınız?

İbiş Ağa: Hay anasını, şaşırdık tüh!

Fitne Kumkuması: Aman efendim, dikkat ediniz, dikkat!

İbiş Ağa: Evet, evet. Dikkat edeyim dostum. (Kendi kendine) Ah, ne güzel adam! Hiç eşini bulamadım. (Aşkâre) Baksana ayol! Bu yol nereye gider ha? Sana söylüyorum (Erkek sesiyle bağırarak) Söylesene be!

Fitne Kumkuması: (Telaşla) Ne yaptınız? Yine şaşırdınız!

İbiş Ağa: Hay Allah layığımı versin! Hiç aklım başımda değil! (Yine karı taklidiyle) Şey ayol sana söylüyorum, bu yol nereye gider? Abo canım, abo! Ben kadınım, hiç insafın yok mu canım?

Fitne Kumkuması: Pekâlâ, pekâlâ efendim. İşte böyle, lakin efendim bir kusurunuz daha var!

İbiş Ağa: (Telaşla) Aman nedir? Rica ederim söyleyiniz.

[31] Fitne Kumkuması: Şey efendim, baksanıza, o cemalinizdeki yaşmak gayet ince gelmiş de hüsnünüz halel getirmiş. Şunun bir parça kalıncasını bulup getireyim. Daha iyi olmaz mı?

İbiş Ağa: Pekâlâ ama şu bıyık ile sakala ne çare bulalım?

Fitne Kumkuması: A, zararı yok efendim. Zararı yok. Kalınca yaşmak olunca hepsini kaybeder, esef etmeyin efendim esef etmeyin!

İbiş Ağa: Ah eksik olma benim hakikatli dostum! Allah senin ne muradın varsa versin ki şu belalardan beni halas ettiğin için. Ne diyeyim? Rabbim, Rabbim, ya Rabbim, ne kadar bütün unuttuğum dualar varsa hep senin olsun, âmin!

Fitne Kumkuması: Var olun efendim! Bendeniz gideyim de şu yaşmağı getireyim.

İbiş Ağa: Lakin ben yalnız ne yaparım burada?

Fitne Kumkuması: Beis yok efendim. Bendeniz şimdi gelirim.

İbiş Ağa: Rica ederim, çok geç kalmayın. Zira korkuyorum.

Fitne Kumkuması: Hayır efendim. Hayır, bendeniz şimdi gelirim. (Gider) 


\section{Üçüncü Meclis}

İbiş Ağa-İki Delikanlı

Birinci Delikanlı: Lakin birader, görmeliydin. Çarşı içinden bir geçiş geçti! Aman efendim, aman! O eda, o yürüyüş, o bakış! Artık sorma, sorma...

İkinci Delikanlı: Ne faydası var! İşittiğime göre vefasız bir şeymiş galiba.

Birinci Delikanlı: Kim demiş onu sana? Söyleyen adeta hasedinden naşi söylemiş olmalı.

İkinci Delikanlı: Vah bilmem. İşittiğimi söylüyorum.

İbiş Ağa: (Kendi kendine) Acaba bu delikanlılar kim? Lakin nerede kaldı? Ben korkmağa başladım!

Birinci Delikanlı: Bir kere görsen! Sen de anlarsın a!

İkinci Delikanlı: Bana lüzumu yok. Herkesinki kendine oluyor.

Birinci Delikanlı: A! Öyle ya! Öyle ya! Hakkınız var birader!

İbiş Ağa: (Yine kendi kendine) Şimdi patlayacağım. Bu nerede kaldı ya?

[32] İkinci Delikanlı: (İbiş’i görerek arkadaşına hitaben) Baksana birader. Şurada bir kelepir var!

Birinci Delikanlı: Kim o? Nasıl şey? (İbiş’e bakıp yaklaşarak)

İkinci Delikanlı: (İbiş’e) Maşallah güzel hanımefendim! Teşrifler nereye civanım?

İbiş Ağa: (Karı taklidiyle) Abo, a canım abo... A... Ayol bir genç kadını yalnız bulurlarsa böyle mi ederler? A, üstüme iyilik sağlık!

Birinci Delikanlı: Canım efendim, kerem edin. Hiddet buyurmayın. Kulunuz ayak turabıyım. Fakat efendimin takdiri bizlere aynı iltifattır. Efendiciğim?

İbiş Ağa: A! Ayol nasıl şeysiniz siz? (Kendi kendine telaşla) Nerede de kaldı o musibet? (Aşkâr) Bırakın beni! Ben sizin bildiğiniz kadınlardan değilim!

İkinci Delikanlı: Ne zararı var efendim? Biz sizi pek çabuk tanırız. Lütfedin. Teşrifler nereye efendim?

İbiş Ağa: (Hiddetle kendi kendine) Cehenneme çapkınlar, ne vazifeniz! (Yine taklitle) A canım siz ne arsız şeysiniz! Kendi yolunda giden bir kadına takılmak ayıptır a! 
Birinci Delikanlı: (İbiş’i çimdikleyerek) Bizi kabul etmez misiniz?

İbiş Ağa: Of! Elin kırılsın, kuvvetli kopardı. A nasıl da acıdı! Ayol git işine diyorum, düşme benim peşime.

İkinci Delikanlı: Ha, evet güzel şarkıdır, haydi çocuk işine, düşme benim peşime, değil mi efendim?

Birinci Delikanlı: Birader, hakikaten takatim kalmadı. Ayıp değil a ben öpeceğim!

İbiş Ağa: A vallahi, olmaz! Şimdi yangın var diye bağırırım.

İkinci Delikanlı: Biz adamı bırakır mıyız ya! (Çimdiklerler)

İbiş Ağa: Of, canım ne acıtıyorsunuz! A, ya kocam görürse?

Birinci Delikanlı: Vay, kocanız da mı var?

İbiş Ağa: Hiç kocasız kadın sokakta gezer mi ayol? Abo!

[33] İkinci Delikanlı: Varsın olsun! Ne zararı var efendiciğim? Bizi de kabul buyurursunuz! İbiş Ağa: Hiç öyle şey mi olur ayol!

\section{Dördüncü Meclis}

\section{Evvelkiler-Bir Sekban}

Sekban: Ey bana bakın delikanlılar! İşiniz ne sizin burada bakayım?

Delikanlılar (Korkarak ikisi birden) Hayır efendim, hiç... Şey...

İkinci Delikanlı: (Birinciye) Gördün mü? Şimdi ne diyeceğiz?

Birinci Delikanlı: Efendim, bendeniz, şey...

Sekban: Bu kadına hanginiz takılıyordu ha?

İkinci Delikanlı: Hayır efendim, hiçbirimiz, hiçbirimiz.

Sekban: (Bağırarak) Doğru söyleyin bire!

İbiş Ağa: Canım, ağa. Bunlardan hiç rahat yok. Karı kısmı zahir şerlerinden sokağa çıkmamalı!

Sekban: Haydi oradan defolun bakayım. 
Birinci Delikanlı: Efendim, benim kabahatim yok. (Gider)

İkinci Delikanlı: Hayır efendim, ben takılmadım. O takıldı. (Gider)

İbiş Ağa: İkisi de çapkının dik ağlası!

Sekban: Haydi kadın, sen de yoluna git.

İbiş Ağa: Peki efendim. Allah sizden razı olsun. (Giderek kendi kendine) Ah, uğursuz dostum nerede kaldı? Yere mi battı acaba?

Sekban: Bana baksana canım azıcık, dur bakayım.

İbiş Ağa: Vay vay vay vay... Şimdi battın işte! Neredesin herif, nerede? Gel de halimi gör!

Sekban: Sen kimin nesisin bakayım?

İbiş Ağa: Şey efendim, ben şeyim şey... (Kendi kendine) Ne diyeceğimi de şaşırdım!

Sekban: Hayır, benim senden azıcık şüphem var da...

İbiş Ağa: Aman yarabbi! Şimdi bayılacağım! (Aşkâre) Canım siz de mi bana musallat oldunuz?

[34] Sekban: Hayır, hayır. Anlayacağım. Şey var...

İbiş Ağa: Nedir canım, ne istersiniz? (Kendi kendine) Yerin dibine geçesi dostum nerede kaldı?

Sekban: Söyle bakayım, sen kimin haremisin ha?

İbiş Ağa: Ben efendim, şeyin haremiyim... (Kendi kendine) Acaba kimin haremiyim? Unuttum gitti. (Aşkâre) Adım şeydir efendim, şey...

Sekban: (Bağırarak) Ne söylüyorsun be?

İbiş Ağa: Hay Allah cezanı versin! Ne diyeyim canım ben de şaşırdım!

Sekban: Dindi de... Söyle!

\section{Beşinci Meclis}

İbiş Ağa-Sekban-Fitne Kumkuması

Fitne Kumkuması: (Koşarak) Aman ne oldunuz canım, ne var?

İbiş Ağa: (Fitneye hitaben) Neredesin canım? Gel beni kurtar! Bittim efendim, bittim. 
Fitne Kumkuması: (İbiş’e) Siz esef etmeyin. (Sekban'a) Canım ne istersiniz elin yolcusundan?

Sekban: Vay, bu kadın yolcu mudur?

Fitne Kumkuması: Evet efendim, yolcudur yolcu.

Sekban: Ey öyledir de burada bir takım delikanlılarla işi ne?

Fitne Kumkuması: Ne bilsin ey efendim, acemi hatun.

Sekban: Nereye gidecek kendisi?

İbiş Ağa: (Fitne’ye gizliden) Kendi memleketine de, kendi memleketine!

Fitne Kumkuması: Kendi memleketine efendim. Şu yoldan gidecek, şu yoldan.

Sekban: Ya öyleyse birlikte gidelim de yolda kimse takılmasın.

Fitne Kumkuması: Peki efendim. Allah razı olsun.

İbiş Ağa: Canım nasıl olur ya?

Fitne Kumkuması: Zararı yok efendim, zararı yok. (Sekban'a) Peki efendim, alın da birlikte götürün.

Sekban: Ey, haydi öyleyse.

[35] İbiş Ağa: (Fitne Kumkuması'nın boynuna sarılıp ağlayarak) Allah 1smarladık dostum. Allah seni bu diyardan eksik etmesin. Sen beni her beladan kurtardın (diyip musafaha ederek gider).

\section{Altıncı Meclis}

Fitne Kumkuması (Yalnız)

(İbiş Ağa'nın arkasından bakarak) Hah hah hah, git behey öküz herif git. Bak kolaylıkla insan lob şekeri gibi şehir kızını yutar mıymış? İşte var anla da, gittiğin yerde bir de beni medh et. Ey şimdi bunu atlattık ama kızın babasını nasıl etmeli şimdi iş onda kaldı. Herifi epeyce kandırdık bir takım hilelerle inandırdık ama şimdi yüzdük yüzdük işin kuyruğuna geldik. Ah Fettan! Ben bu işi kimseye yapmam ama ne fayda ki seni kendime bir kere refik-i sadık addettim. Yoksa değil kızı, kızın hayalini bile göremeyecektin. Lakin hile bazı yerde işe yarıyor. Hiç olmazsa böyle iki âşık ve maşuku bir araya getirmeğe sebep oluyor. Vâkıâ indü'n-nasda mezmum şey. (Bu aralık uzaktan Musa Ağa'nın geldiğini görerek) Hah tamam işte Elmas Hanım'ın babası da geliyor. Hay anasını! Şimdi son karar buna ne yol bulmalı? (Biraz düşünerek) Tamam tamam bu yolunda. (Ağlamağa başlar) 


\section{Yedinci Meclis}

Fitne Kumkumas1-Musa Ağa

Fitne Kumkuması: (Ağlayarak) Ah, h1... h1... h1... h1... h1... h1... h1...

Musa Ağa: Bu ne? Bu adama ne oldu acaba?

Fitne Kumkuması: (Yine ağlayarak) H1... hı... hı... Ah zavallı adamcağız, kim bilir şimdi... Musa Ağa: (Kendi kendine) Ne var acaba? Baksana yahu!

Fitne Kumkuması: (Kezâlik) Ah, ah... Zavallı ihtiyar! Vah zavallı adamcağız vah!

Musa Ağa: (Yanına gelip dürterek) Canım ne var söylesene!

Fitne Kumkuması: (Musa Ağa’yı görerek) Ah! Sizin... Efendim, sizin... Sizin... Ah, ah! Musa Ağa: (Ağlayarak) Ne oldu bizim... Ha?

Fitne Kumkuması: (Kezalik) Ah, sizin... Şeyiniz... Ah! Efendim, sizin... Vah vah vah! Musa Ağa: (Kezalik) Vah vah vah, bizim... Ey, ne oldu?

[36] Fitne Kumkuması: (Kezalik) Ah sizin... Oh sizin... Oh sizin... Hı hı hı hı...

Musa Ağa: (Kezalik) Ey! Canım ne oldu söylesene!

Fitne Kumkuması: (Kezalik) Sizin... Kızınız... Kızınız... Kızınız... Ah ah ah ah!

Musa Ağa: (Kezalik) Canım, kızım ne oldu? Rica ederim söyle!

Fitne Kumkuması: (Kezalik) Ne olacak? Sizin kızınızı... Kızınızı... Kııınızı... Ah ah ah! Musa Ağa: (Kezalik) Ey sonra ne oldu kızımıza?

Fitne Kumkuması: (Kezalik) Ne olacak? İbiş... İbiş... İbiş... Kızınızı... Kızınızı... Ah ah... Kızınızı...

Musa Ağa: (Kezalik) Canım, İbiş ne oldu? Kızıma bir şey mi yaptı?

Fitne Kumkuması: (Kezalik) Evet efendim, evet. Kızınızı çalıp kaçmasın mı?

Musa Ağa: (Bayılma derecesine gelip) Aman evladımı... Elmas'ımı... Elmas'ımı...

Fitne Kumkuması: (Kezalik) Evet efendim, Elmas Hanım'1, o İbiş dedikleri herif alıp kaçırdı!

Musa Ağa: (Kezalik) Canım nasıl oldu? Ne vakit gitti bu herif?

Fitne Kumkuması: (Ağlamasını keserek) İki üç saat evvel duydum. Alıp gitmiş, köyüne götürmüş. Hatta kızınız razı olmuş bile! 
Musa Ağa: Ne diyorsun! Sahih mi bu iş?

Fitne Kumkuması: Yalandan böyle şey olur mu efendim?

\section{Sekizinci Meclis}

Evvelkiler-Elmas Hanım-Fettan Bey

Fettan Bey: (Elmas Hanım'ı güya yoldan çevirmiş gibi sürükleyerek babasına teslim eder) Alın efendim kızınızı. Bendenize vermeğe her ne kadar ru-yi rıza göstermiyor idiyseniz de yine insaniyetimin iktizası tuz ekmek yediğim için kaçarken yoldan çevirip size getirdim.

[37] Musa Ağa: Eksik olma evladım. İnsaniyetini sahihan belli ettin, aferin. (Kızına hiddetle) Seni gidi utanmaz alçak seni! Babanın elinden kaçıp da eller elinde sefa sürecektin, öyle mi?

Elmas Hanım: (Yalandan ağlayarak) Ben nişanlımı isterim, ben nişanlımı isterim (Hem tepinir hem ağlar).

Musa Ağa: Sana nişanlı şimdiden sonra dayak. Seni gidi kahpe seni!

Elmas Hanım: (Kezalik) Ben kocamı isterim! Ben kocamı isterim.

Musa Ağa: Vermeyeceğim seni o herife! Ben seni vereceğim adamı biliyorum.

Elmas Hanım: (Telaşla) Kime?

Musa Ağa: (Fettan Bey’i göstererek) İşte!

Elmas Hanım: (Suni surette ağlayarak) Ben istemem! Ben istemem!

Fettan Bey: (Elmas Hanımla hafiyen birbirlerine işaret ederek) Hayır efendim, hayır! Mademki bendenizi istemiyorlar... Kulunuz da kabul etmem belki...

Musa Ağa: Ne demek! Ben babası değilim! (Kızına hitaben) Gel buraya bakalım (Elmas Hanım yavaş yavaş gelir. Musa Ağa elini tutup Fettan Bey’in eline vererek bir taraftan İbiş yaşmağını açmış olduğu halde, bu hale taaccüple bakarak) Hah, işte şimdi muradım hasıl oldu. Haydi bakalım.

İbiş Ağa: Vay anasını! Meğerse bana olan işler hep dolapmış ha! Bravo! Bizim dost efendi bravo!

(Der ve son perde olan üçüncü perde dahi iner)

Hitam. 